\title{
A robust metal-organic framework containing benzoselenadiazole for highly efficient aerobic cross-dehydrogenative coupling reactions under visible
}

\section{light}

Wen-Qiang Zhang, ${ }^{\dagger, \#}$ Qiu-Yan Li, ${ }^{\dagger, \#}$ Quan Zhang, ${ }^{\ddagger}$ Yingqiao Lu, ${ }^{\dagger}$ Han Lu, ${ }^{\dagger}$ Wenguang Wang, ${ }^{\S}$ Xinsheng Zhao" and Xiao-Jun Wang*,

"Jiangsu Key Laboratory of Green Synthetic Chemistry for Functional Materials, School of Chemistry and Chemical Engineering, Jiangsu Normal University, Xuzhou 221116, P. R. China.

E-mail: xjwang@jsnu.edu.cn (X.-J. Wang)

${ }^{\ddagger}$ Key Laboratory of Carbohydrate Chemistry and Biotechnology, Ministry of Education, School of Biotechnology, Jiangnan University, Wuxi 214122 , P. R. China.

${ }^{\S}$ School of Chemistry and Chemical Engineering, Shandong University, Jinan 250100, P. R. China.

"School of Physics and Electronic Engineering, Jiangsu Normal University, Xuzhou 221116, P. R. China.

\# These authors contributed equally. 


\section{General method and materials}

Unless specifically mentioned, all chemicals are commercially available and were used as received. Tetrahydrofuran (THF) and triethylamine (TEA) were distilled over sodium/benzophenone ketyl and $\mathrm{CaH}_{2}$ under a nitrogen atmosphere prior to use, respectively. NMR spectra were taken on a Bruker AV400 at room temperature. The powder X-ray diffraction (PXRD) measurements were taken on a Bruker D8 diffractometer using $\mathrm{Cu}-K_{\alpha}$ radiation $(\lambda=1.5418 \AA)$ at room temperature. UV-vis spectra were obtained on a PuXi TU-19 spectrophotometer. The solid states UV-Vis spectra were acquired using the Thermo Scientific Evolution 220 spectrophotometer equipped with integrating sphere and recorded in absorbance vs. wavelength modes using appropriate baseline correction (Zero/baseline correction). ESR spectra were recorded at room temperature using a Bruker ESP-300E spectrometer at $9.8 \mathrm{GHz}, \mathrm{X}$-band, with $100 \mathrm{~Hz}$ field modulation. Thermogravimetric analysis (TGA) was carried out on a TGA-Q500 thermoanalyzer with a heating rate of $10{ }^{\circ} \mathrm{C} / \mathrm{min}$ under nitrogen atmosphere. Low-pressure gas sorption measurements were performed by using Quantachrome Instruments Autosorb-iQ (Boynton Beach, Florida USA) with the extra-high pure gases.

\section{Synthesis and Characterizations}

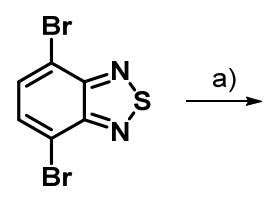

3

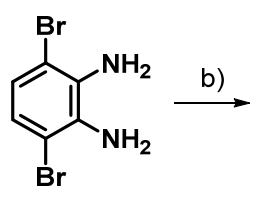

4

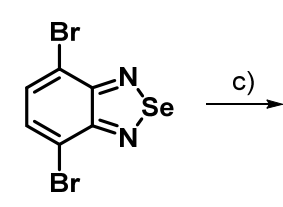

5
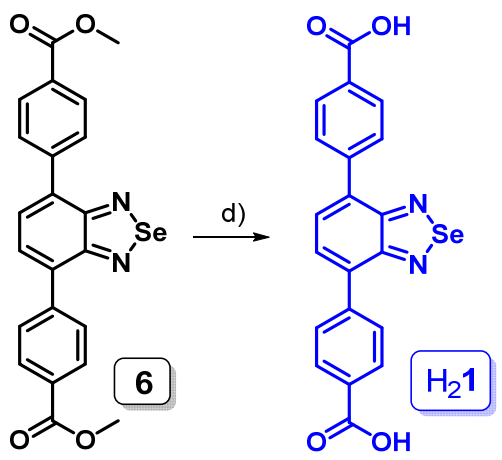

Scheme S1 The synthetic route of $\mathrm{H}_{2} 1$. Reagents and conditions: a) $\mathrm{NaBH}_{4}, \mathrm{CoCl}_{2}, \mathrm{EtOH}$, reflux for $4 \mathrm{~h}$; b) $\mathrm{SeO}$, EtOH- $\mathrm{H}_{2} \mathrm{O}$, reflux for $8 \mathrm{~h}$; c) methyl 4-boronobenzoate, $\mathrm{Cs}_{2} \mathrm{CO}_{3}, \mathrm{CsF}, \mathrm{Pd}(\mathrm{dppf}) \mathrm{Cl}_{2}, \mathrm{Pd}\left(\mathrm{PPh}_{3}\right)_{4}, \mathrm{THF} / \mathrm{H}_{2} \mathrm{O}, 70{ }^{\circ} \mathrm{C}$ for $2 \mathrm{~d}$; d) $\mathrm{KOH}, \mathrm{THF}, \mathrm{CH}_{3} \mathrm{OH}, 90{ }^{\circ} \mathrm{C}$ for $20 \mathrm{~h}$; TFA, THF, $12 \mathrm{~h}$, room temperature.

Compound 4: 4,7-dibromo-2,1,3-benzothiadiazole (5.0 g, $17.0 \mathrm{mmol})$, $\mathrm{NaBH}_{4}(1.29 \mathrm{~g}, 34.1 \mathrm{mmol})$ and $\mathrm{CoCl}_{2} \cdot 6 \mathrm{H}_{2} \mathrm{O}(0.41 \mathrm{~g}, 1.7 \mathrm{mmol})$ were dissolved in $200 \mathrm{~mL} \mathrm{EtOH}$, which was refluxed for $4 \mathrm{~h}$ at $90{ }^{\circ} \mathrm{C}$. After that, the mixture was cooled to room temperature. The mixture was separated through the suction filter. The filter liquor was extracted by DCM $(400 \mathrm{~mL})$ and washed with water $(400 \mathrm{~mL}$ x 3). The organic layer was dried over anhydrous $\mathrm{Na}_{2} \mathrm{SO}_{4}$ and the solvents were removed under 
reduced pressure. The crude product was purified by silica gel flash column chromatography (DCM/Petroleum ether, 1/1) to afford the pure product as white solid (4.1 g, 15.4 mmol, yield: 91\%). ${ }^{1} \mathrm{H}$ NMR (400 MHz, $\left.\mathrm{CDCl}_{3}\right) \delta 6.85$ (s, 2H), 3.89 (br, 4H).

Compound 5: Compound 4 (3.0 g, $11.3 \mathrm{mmol}$ ) were dissolved in EtOH $(900 \mathrm{~mL})$. Then $\mathrm{SeO}_{2}(1.3 \mathrm{~g}$, $11.4 \mathrm{mmol}$ ) were dissolved in hot water and the solution was added dropwise into the mixture which was refluxed for $8 \mathrm{~h}$ at $85^{\circ} \mathrm{C}$. After cooling to room temperature, the reaction was separated through the suction filter to afford the yellow solid which was washed with EtOH $(3.5 \mathrm{~g}, 10.3$ mmol, yield: 91\%). ${ }^{1} \mathrm{H}$ NMR (400 MHz, $\left.\mathrm{CDCl}_{3}\right) \delta 7.64$ (s, 2H).

Compound 6: A mixture of $\mathrm{Cs}_{2} \mathrm{CO}_{3}(10.0 \mathrm{~g}, 30.6 \mathrm{mmol})$ and $\mathrm{CsF}(0.78 \mathrm{~g}, 5.1 \mathrm{mmol})$ were dissolved in water $(2 \mathrm{~mL})$ and added into a $250 \mathrm{~mL}$ round bottom flask with a magnetic stir bar. Dried and degassed THF $(100 \mathrm{~mL})$ was added to the reaction flask and the reaction mixture was degassed by sparging with $\mathrm{N}_{2}$ for $2 \mathrm{~h}$. Then, compound 5 (3.5 g, $10.2 \mathrm{mmol}$ ), methyl 4-boronobenzoate (4.2 g, $23.5 \mathrm{mmol}), \mathrm{Pd}(\mathrm{dppf}) \mathrm{Cl}_{2}(0.75 \mathrm{~g}, 1.02 \mathrm{mmol})$ and $\mathrm{Pd}\left(\mathrm{PPh}_{3}\right)_{4}(0.35 \mathrm{~g}, 0.31 \mathrm{mmol})$ were added into the mixture. The round bottom flask was vacuumed and pushed into $\mathrm{N}_{2}$ for 5 times. The reaction was heated at $70{ }^{\circ} \mathrm{C}$ for 48 hours under an argon atmosphere. After that, the reaction mixture was cooled down to room temperature and extracted by DCM (200 mL x 2). The combined organic layer was washed with water $\left(400 \mathrm{~mL}\right.$ x 3), and dried over anhydrous $\mathrm{Na}_{2} \mathrm{SO}_{4}$ then evaporated under reduced pressure. The crude product was further purified using column chromatograph $\left(\mathrm{DCM} / \mathrm{CH}_{3} \mathrm{COOC}_{2} \mathrm{H}_{5}\right.$, 100/6) to give orange solid (3.7 g, $8.2 \mathrm{mmol}$, yield: 80\%). ${ }^{1} \mathrm{H}$ NMR (400 MHz, $\left.\mathrm{CDCl}_{3}\right) \delta 8.21(\mathrm{~d}, J=$ $8.4 \mathrm{~Hz}, 4 \mathrm{H}), 7.98(\mathrm{~d}, J=8.4 \mathrm{~Hz}, 4 \mathrm{H}), 7.71(\mathrm{~s}, 2 \mathrm{H}), 3.97(\mathrm{~s}, 6 \mathrm{H})$.

$\mathbf{H}_{2}$ 1: Compound $\mathbf{6}(0.84 \mathrm{~g}, 1.86 \mathrm{mmol})$ was dissolved in THF $(100 \mathrm{~mL})$ and added into a $250 \mathrm{~mL}$ round bottom flask with a magnetic stir bar. $\mathrm{KOH}(1.10 \mathrm{~g}, 19.64 \mathrm{mmol})$ was dissolved in $\mathrm{MeOH}(20$ $\mathrm{mL}$ ) and added into the mixture which was refluxed for $20 \mathrm{~h}$ at $90{ }^{\circ} \mathrm{C}$. After cooling to room temperature, the reaction was separated through the suction filter to afford the yellow solid which was washed with THF (200 mL x 5). Then the solid was dissolved in THF (100 mL) and TFA (10 $\mathrm{mL}$ ) was added. The reaction was stirred for 12 hours. Then the solution was obtained by centrifugal to get the crude product, which was further washed by EtOH and water (1/1) to give deep yellow powder solid (0.65 g, $1.54 \mathrm{mmol}$, yield: 83\%). ${ }^{1} \mathrm{H}$ NMR (400 MHz, DMSO- $\left.d_{6}\right) \delta 13.04(\mathrm{~s}, 2 \mathrm{H}), 8.08$ $(\mathrm{s}, 8 \mathrm{H}), 7.86(\mathrm{~s}, 2 \mathrm{H}) .{ }^{13} \mathrm{C}$ NMR $\left(101 \mathrm{MHz}, \mathrm{DMSO}-d_{6}\right) \delta 167.2,158.3,141.8,133.7,130.2,129.6$, $129.3,128.6$. 


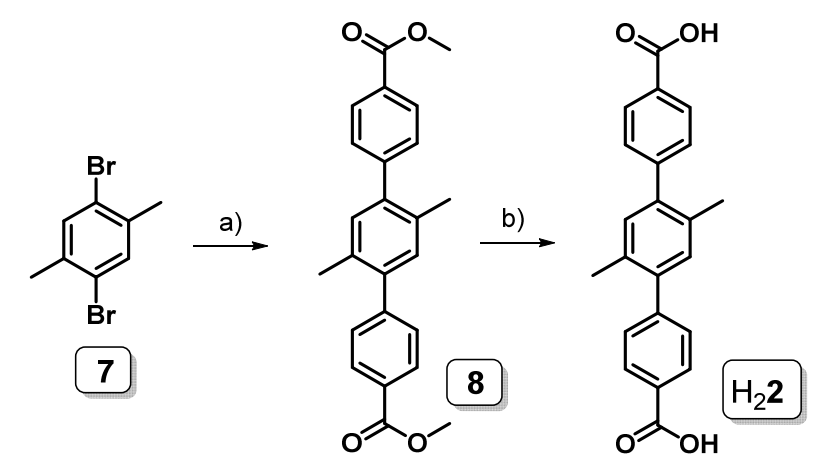

Scheme S2 The synthetic route of $\mathrm{H}_{2}$ 2. Reagents and conditions: a) methyl 4-boronobenzoate, $\mathrm{Cs}_{2} \mathrm{CO}_{3}, \mathrm{CsF}$, $\mathrm{Pd}\left(\mathrm{PPh}_{3}\right)_{4}, 1,4$-dioxane $/ \mathrm{H}_{2} \mathrm{O}, 110{ }^{\circ} \mathrm{C}$ for $1.5 \mathrm{~d}$; b) $\mathrm{KOH}, \mathrm{THF}, \mathrm{CH}_{3} \mathrm{OH}, 90^{\circ} \mathrm{C}$ for $20 \mathrm{~h}$; TFA, THF, $12 \mathrm{~h}$, room temperature.

Compound 8: A mixture of $\mathrm{Cs}_{2} \mathrm{CO}_{3}(11.1 \mathrm{~g}, 34.1 \mathrm{mmol})$ and $\mathrm{CsF}(0.86 \mathrm{~g}, 5.68 \mathrm{mmol})$ were dissolved in water $(2 \mathrm{~mL})$ and added into a $250 \mathrm{~mL}$ round bottom flask with a magnetic stir bar. 1,4-dioxane $(100 \mathrm{~mL})$ was added to the reaction flask and the reaction mixture was degassed by sparging with $\mathrm{N}_{2}$ for $2 \mathrm{~h}$. Then compound 7 (3.0 g, $11.4 \mathrm{mmol})$, methyl 4-boronobenzoate $(6.2 \mathrm{~g}, 34.1 \mathrm{mmol})$ and $\mathrm{Pd}\left(\mathrm{PPh}_{3}\right)_{4}(1.31 \mathrm{~g}, 1.14 \mathrm{mmol})$ were added into the mixture. The round bottom flask was vacuumed and pushed into $\mathrm{N}_{2}$ for 5 times. The reaction was heated at $110{ }^{\circ} \mathrm{C}$ for 36 hours under an argon atmosphere. The reaction mixture was cooled down to room temperature and extracted by DCM (200 $\mathrm{mL} \times 2)$, then the mixture was washed with water $(400 \mathrm{~mL} \times 3)$. The organic layer was collected and dried over anhydrous $\mathrm{Na}_{2} \mathrm{SO}_{4}$ then evaporated under reduced pressure. The crude product was further purified using column chromatograph (DCM/EtOAc, 1/1) to give white solid (3.9 g, $10.4 \mathrm{mmol}$, yield: 92\%). ${ }^{1} \mathrm{H}$ NMR (400 MHz, $\left.\mathrm{CDCl}_{3}\right) \delta 8.11(\mathrm{~d}, J=8.4 \mathrm{~Hz}, 4 \mathrm{H}), 7.45$ (d, $\left.J=8.4 \mathrm{~Hz}, 4 \mathrm{H}\right), 7.16$ (s, 2H), $3.95(\mathrm{~s}, 6 \mathrm{H}), 2.27(\mathrm{~s}, 6 \mathrm{H})$.

$\mathbf{H}_{2}$ 2: Compound $8(3.9 \mathrm{~g}, 10.4 \mathrm{mmol})$ was dissolved in THF $(100 \mathrm{~mL})$ and added into a $250 \mathrm{~mL}$ round bottom flask with a magnetic stir bar. $\mathrm{KOH}(5.8 \mathrm{~g}, 104.2 \mathrm{mmol})$ was dissolved in $\mathrm{MeOH}$ $(20 \mathrm{~mL})$ and added into the mixture which was refluxed for $20 \mathrm{~h}$ at $90{ }^{\circ} \mathrm{C}$. After cooling to room temperature, the reaction was separated through the suction filter to afford the white solid which was washed with THF (200 mL x 5). Then the solid was dissolved in THF (100 mL) and TFA (12 mL) was added. The reaction was stirred for 2 hours. Then the solution was obtained by centrifugal to get the crude product, which was further purified with EtOH and water (1/1) to give white powder solid (3.1 g, 8.9 mmol, yield: 86\%). ${ }^{1} \mathrm{H}$ NMR (400 MHz, DMSO-d $\left.d_{6}\right) \delta 12.99$ (s, 2H), 8.02 (d, $J=8.3 \mathrm{~Hz}$, 4H), $7.52(\mathrm{~d}, J=8.3 \mathrm{~Hz}, 4 \mathrm{H}), 7.20(\mathrm{~s}, 2 \mathrm{H}), 2.24(\mathrm{~s}, 6 \mathrm{H})$. 


\section{Preparation for metal-organic framework UiO-68M and UiO-68Se}
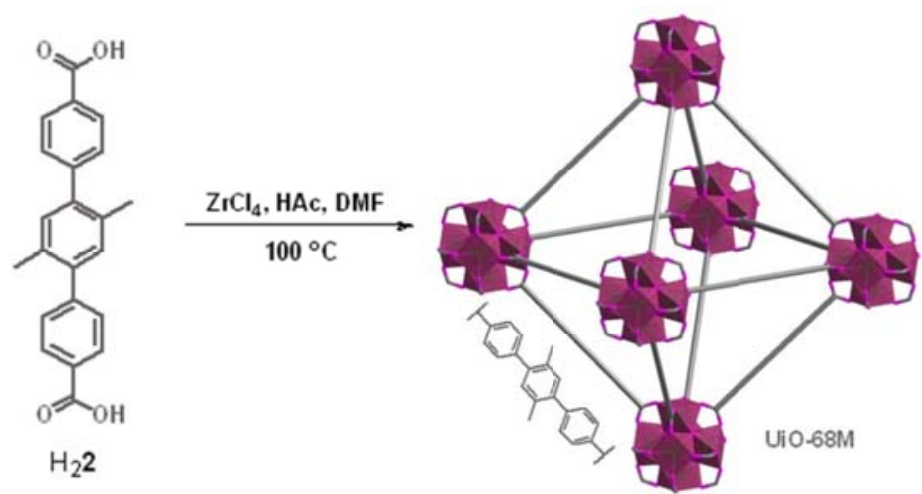

Figure S1 Schematic representation of the preparation for MOF UiO-68M.

MOF UiO-68M: $\mathrm{H}_{2} 2(200 \mathrm{mg}, 0.58 \mathrm{mmol})$ and $\mathrm{ZrCl}_{4}(150 \mathrm{mg}, 0.64 \mathrm{mmol})$ were dissolved in DMF $(100 \mathrm{~mL})$, which was added into a $250 \mathrm{~mL}$ round bottom flask with a magnetic stir bar. Then, HAc $(7.5 \mathrm{~mL}, 0.13 \mathrm{mmol})$ was added to the reaction flask and the reaction mixture was heated at $100{ }^{\circ} \mathrm{C}$ for 48 hours under an argon atmosphere. After cooling to room temperature, the product was separated by centrifugal to afford the white solid which was washed with DMF and EtOH $(100 \mathrm{~mL} x$ 3), respectively; dried in the vacuum in an oven. The powder XRD pattern of product was similar to the simulated pattern generated from single crystal data (Figure S2), confirming its UiO-68 topological framework and the phase purity.

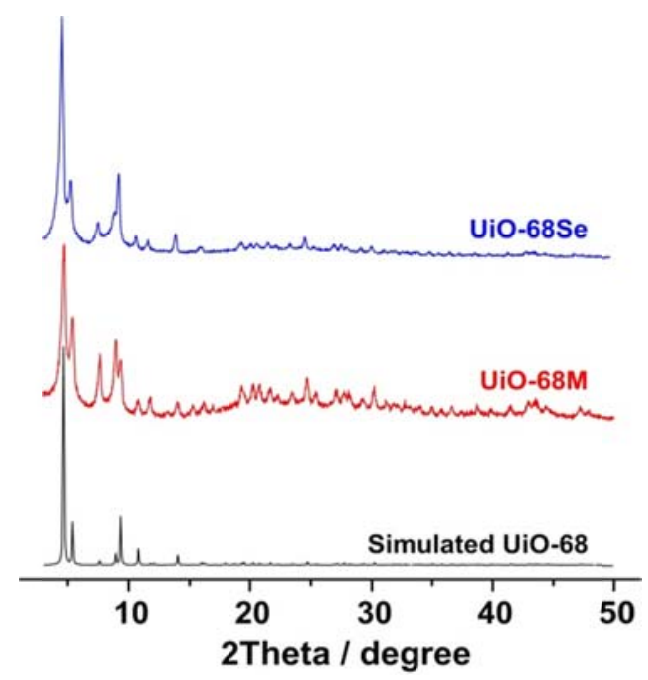

Figure S2 XRD patterns of UiO-68M and UiO-68Se. 

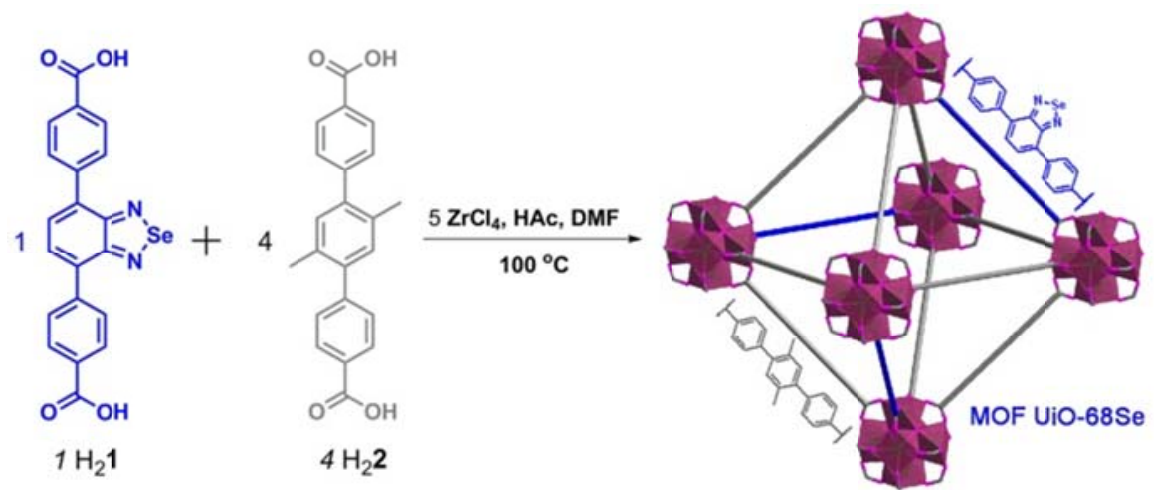

Figure S3 Schematic representation of the preparation for MOF UiO-68Se.

MOF UiO-68Se: $\mathrm{H}_{2} \mathbf{1}(44 \mathrm{mg}, 0.1 \mathrm{mmol}), \mathrm{H}_{2} 2(140 \mathrm{mg}, 0.4 \mathrm{mmol})$ and $\mathrm{ZrCl}_{4}(120 \mathrm{mg}, 0.51 \mathrm{mmol})$ were dissolved in DMF $(100 \mathrm{~mL})$, which was added into a $250 \mathrm{~mL}$ round bottom flask with a magnetic stir bar. Then, HAc $(10 \mathrm{~mL}, 0.17 \mathrm{mmol})$ was added to the reaction flask and the reaction mixture was heated at $100{ }^{\circ} \mathrm{C}$ for 48 hours under an argon atmosphere. After cooling to room temperature, the product was separated by centrifugal to afford the golden solid which was washed with DMF (100 mL x 3) and EtOH (100 mL x 3), respectively. The sample was dried in vacuum. The powder XRD pattern of product was similar to the simulated pattern generated from single crystal data (Fig. S2), confirming its UiO-68 topological framework and the phase purity.

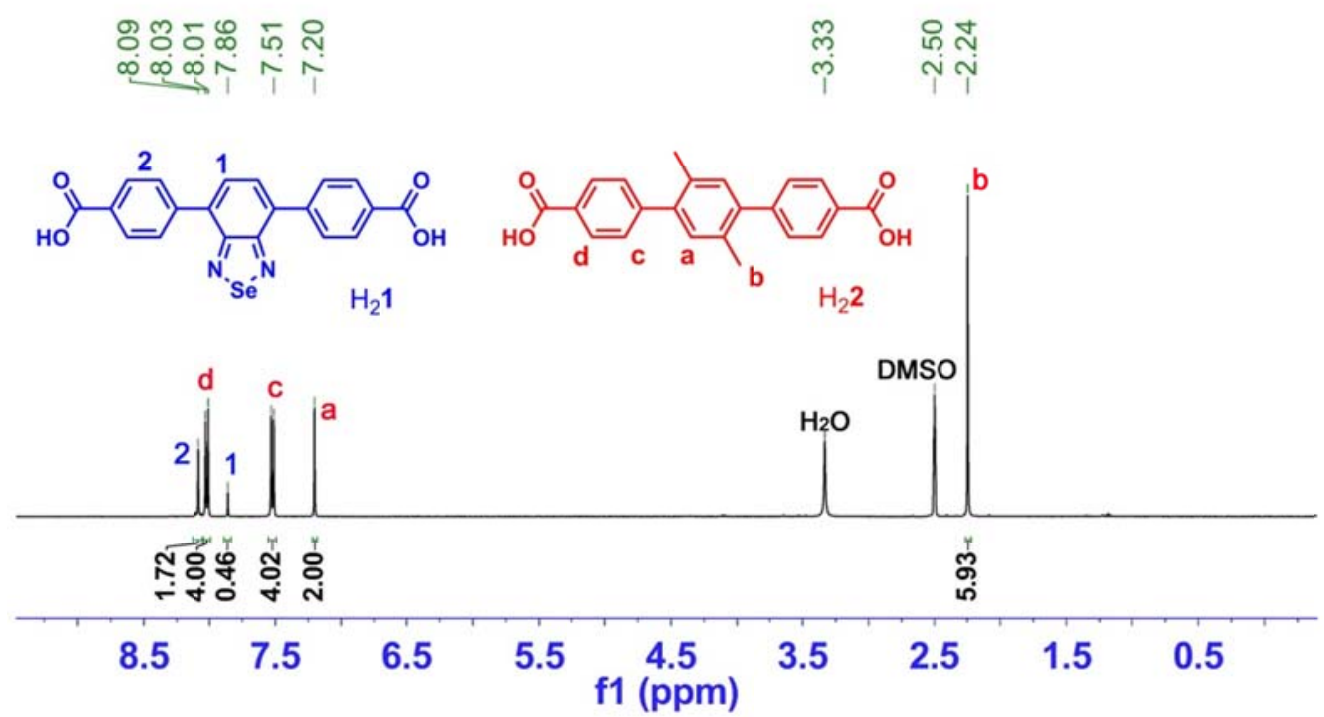

Figure S4 ${ }^{1} \mathrm{H}$ NMR of digested UiO-68Se in DMSO- $d_{6}$. The ratio of linkers $\mathbf{H}_{2} \mathbf{1}$ and $\mathbf{H}_{\mathbf{2}} \mathbf{2}$ in as-prepared MOF UiO-68Se was calculated from the integration of H1 (Linker 1) and Ha (Linker 2), giving the ratio of 1:4.3, which is almost same to the initial ratio of 1:4 in preparation of MOF. 


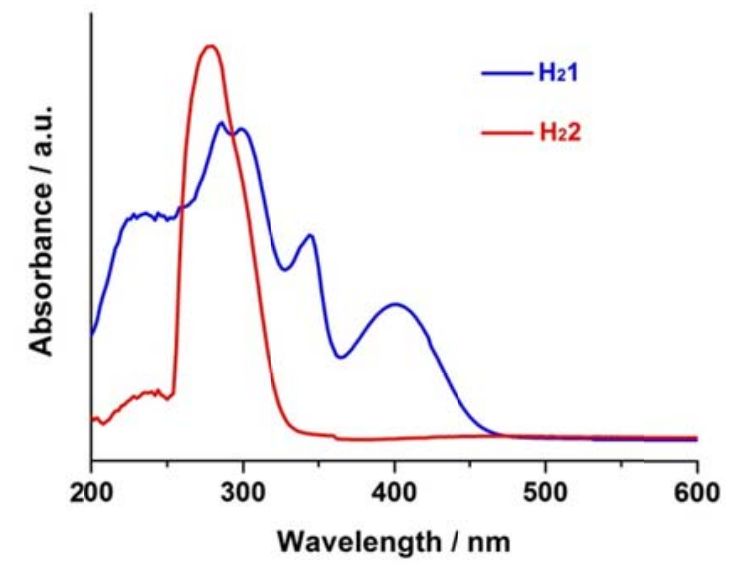

Figure S5 UV-vis absorption of ligands $\mathbf{H}_{2} \mathbf{1}$ and $\mathbf{H}_{2} \mathbf{2}$ in DMSO solution ( $\left.0.1 \mathrm{mM}\right)$.

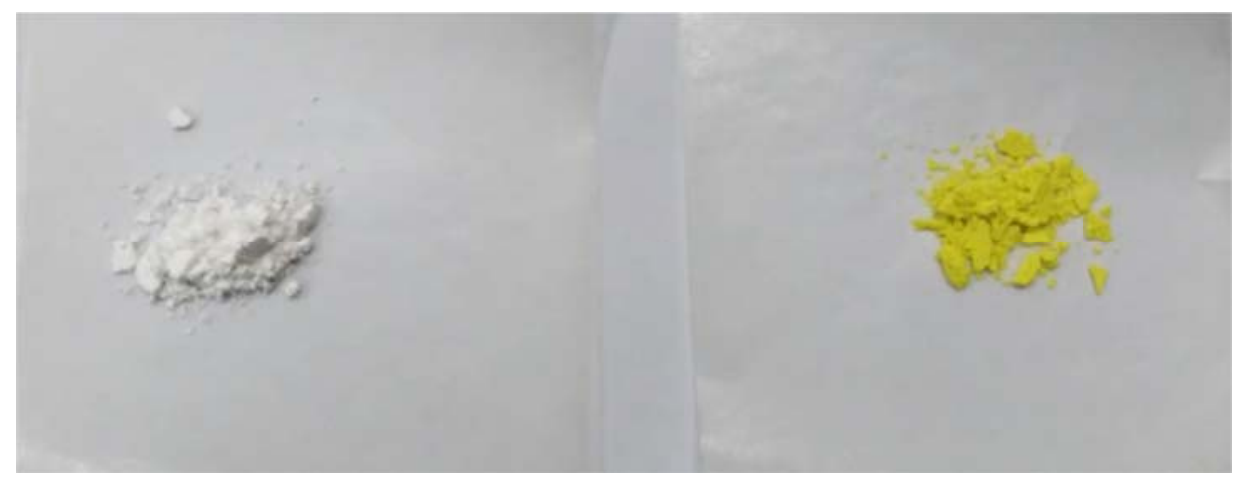

Figure S6 Photographs of MOF UiO-68M (left) and UiO-68Se (right).

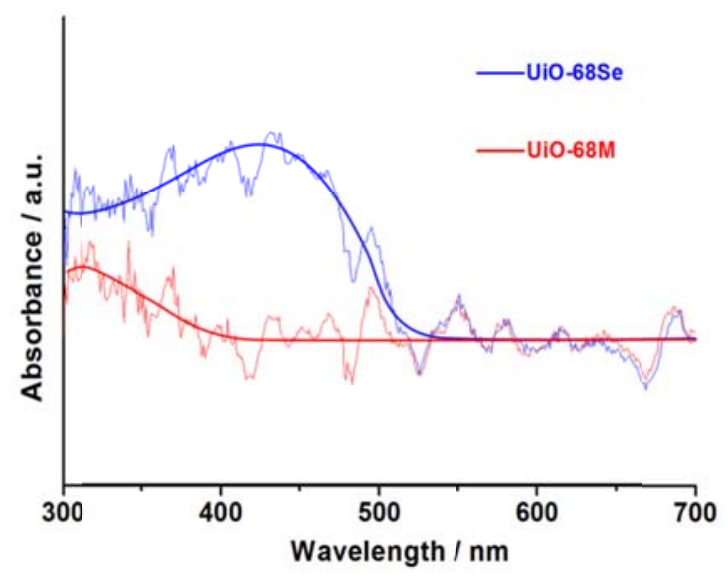

Figure S7 UV-vis spectra of MOF UiO-68Se and UiO-68M in solid state. 


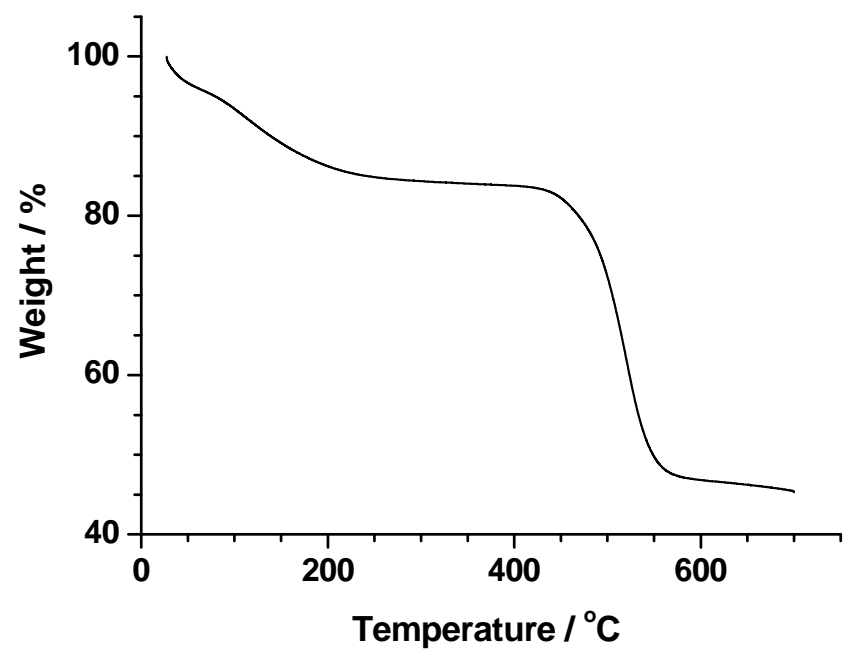

Figure S8 TG curve of MOF UiO-68Se, suggesting it can be stable as high as $\sim 500{ }^{\circ} \mathrm{C}$.
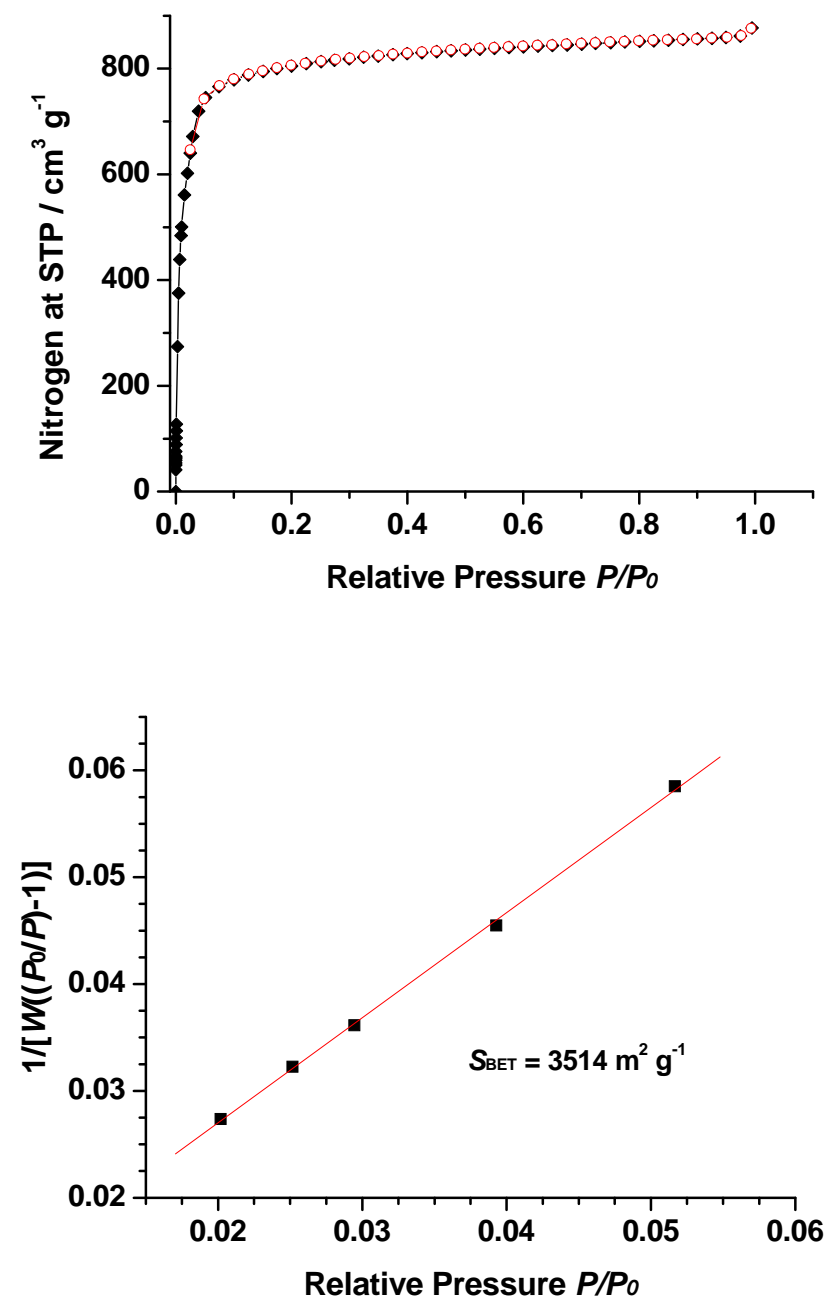

Figure S9 Nitrogen sorption isotherm at 77K (upper) and BET specific surface area plot (bottom) of MOF UiO-68Se. 


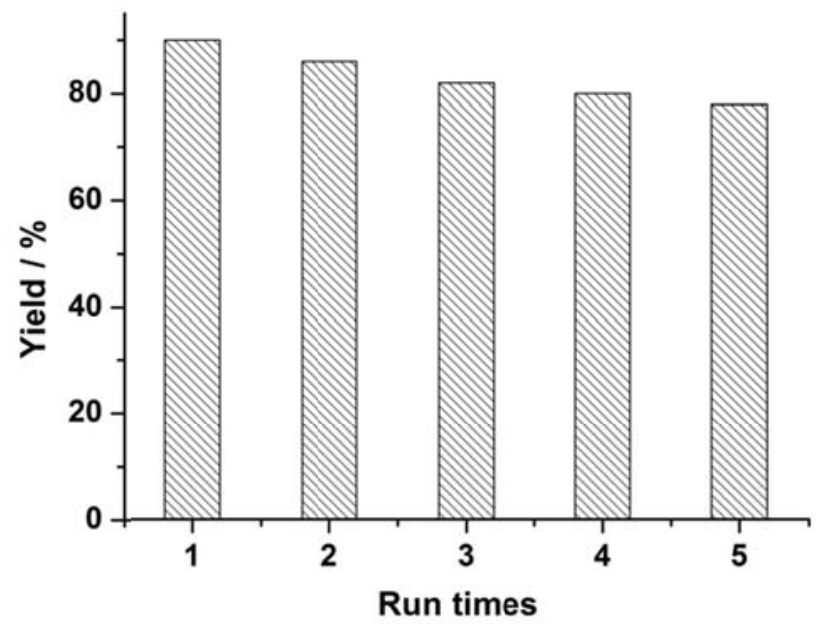

Figure S10 Recycling experiments of UiO-68Se for the reaction of $\mathrm{N}$-phenyltetrahydroiso-quinoline and $\mathrm{CH}_{3} \mathrm{NO}_{2}$.

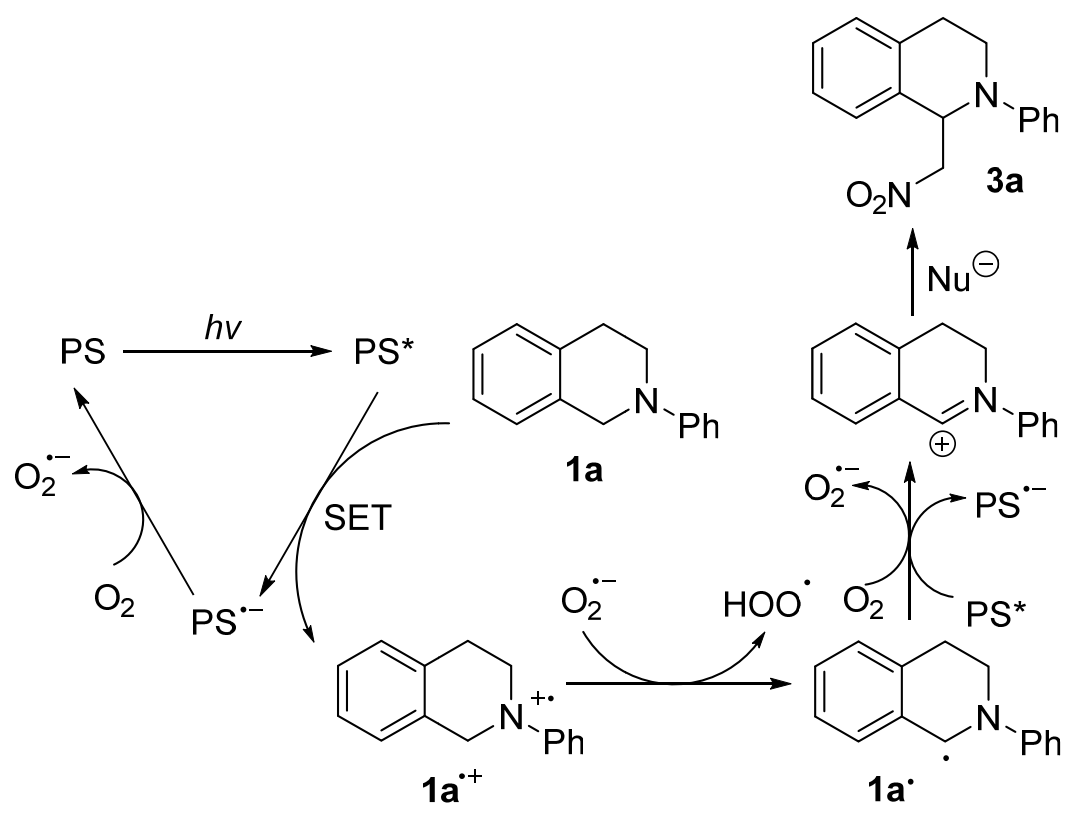

Scheme S3 Proposed mechanism for the photocatalytic aerobic CDC reaction of $N$-phenyltetrahydroisoquinoline and $\mathrm{CH}_{3} \mathrm{NO}_{2}$ with UiO-68Se (PS). 
Table S1 The visible light induced aerobic CDC reactions of tetrahydroisoquinolines 1 with nitroalkanes 2 catalyzed by $\mathrm{UiO}-68 \mathrm{Se}^{a}$

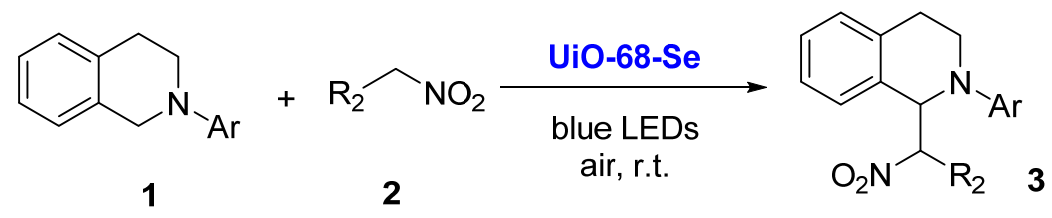<smiles>O=[N+]([O-])CC1c2ccccc2CCN1c1ccccc1</smiles>

3a: $90 \%$<smiles>CC(C1c2ccccc2CCN1c1ccccc1)[N+](=O)[O-]</smiles>

3b: $92 \%(2: 1)$<smiles>Cc1ccc(N2CCc3ccccc3C2C(C)[N+](=O)[O-])cc1</smiles>

3e: $83 \%(1.8: 1)$<smiles>COc1ccccc1N1CCc2ccccc2C1C[N+](=O)[O-]</smiles>

3h: $89 \%$<smiles>O=[N+]([O-])CC1c2ccccc2CCN1c1ccc(Br)cc1</smiles>

3k: $86 \%$<smiles>CCC(C1c2ccccc2CCN1c1ccccc1)[N+](=O)[O-]</smiles>

3c: $89 \%(1.3: 1)$<smiles>CCC(C1c2ccccc2CCN1c1ccc(C)cc1)[N+](=O)[O-]</smiles>

3f: $87 \%(1.4: 1)$<smiles>O=[N+]([O-])CC1c2ccccc2CCN1c1ccc(F)cc1</smiles>

3i: $85 \%$<smiles>CC(C1c2ccccc2CCN1c1ccc(Br)cc1)[N+](=O)[O-]</smiles>

3I: $91 \%(1.8: 1)$

${ }^{a}$ Reaction conditions: $1(0.1 \mathrm{mmol}), 2(1 \mathrm{~mL})$ and UiO-68-Se $(5 \mathrm{mg})$ under air at room temperature with $4 \mathrm{~h}$ irradiation. Yields were determined by ${ }^{1} \mathrm{H}$ NMR spectroscopy using methyl 3,5-dinitrobenzoate as an internal standard. Ratios of the two diastereoisomers are given in parentheses.

\section{General procedure for Aerobic CDC reactions of tetrahydroisoquinolines 1 with nitroalkanes 3} or malonates 4 catalyzed by UiO-68Se: The weighed catalyst $4 \mathrm{mg}$ UiO-68Se and $0.1 \mathrm{mmol} 1$ were added into $1 \mathrm{~mL} \mathrm{CH} \mathrm{CHO}_{2}$ (or $1 \mathrm{~mL}$ malonates). The reaction mixture with stirring was irradiated by blue LEDs for 4 hours under air at room temperature. ${ }^{1} \mathrm{H}$ NMR spectroscopy with methyl 3,5-dinitrobenzoate as an internal standard was employed to determine the yield. The catalyst for cyclic reaction was recycled by centrifugation at $10000 \mathrm{rpm}$ and washed by fresh $\mathrm{CH}_{3} \mathrm{NO}_{2}$ two times. 
General procedure for the Mannich reaction of acetone with tetrahydroisoquinolines: The weighed catalyst $4 \mathrm{mg}$ UiO-68Se, $0.01 \mathrm{mmol}$ L-proline and $0.1 \mathrm{mmol} 1$ were added into $1 \mathrm{~mL}$ acetone. The reaction mixture with stirring was irradiated by blue LEDs for 4 hours under air at room temperature. ${ }^{1} \mathrm{H}$ NMR spectroscopy with methyl 3,5-dinitrobenzoate as an internal standard was employed to determine the yield.

Table S2 The CDC reactions of tetrahydroisoquinolines $\mathbf{1}$ with other nucleophiles catalyzed by UiO-68Se ${ }^{a}$

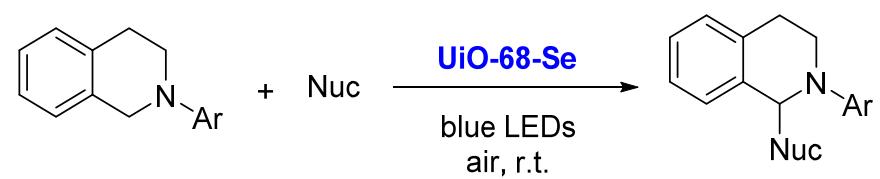<smiles>CC(=O)C1Oc2ccccc2N2CCc3ccccc3C12</smiles>

4a: $88 \%$<smiles>CC(=O)CC1c2ccccc2CCN1c1ccccc1</smiles>

5a: $94 \%$<smiles>CCOC(=O)C1c2ccccc2CCN(c2ccccc2)C1C(=O)OCC</smiles>

4b: $93 \%$<smiles>CC(=O)CC1c2ccccc2CCN1c1ccc(Cl)cc1</smiles>

5b: $88 \%$

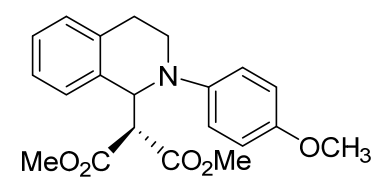

4c: $87 \%$

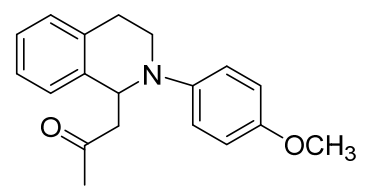

5c: $86 \%$

${ }^{a}$ Reaction conditions: tetrahydroisoquinolines $1(0.1 \mathrm{mmol})$, nucleophiles $(1 \mathrm{~mL})$ and UiO-68-Se $(4 \mathrm{mg})$, ambient air, blue LEDs irradiation for $4 \mathrm{~h}$. Yields detected ${ }^{1} \mathrm{H}$ NMR spectroscopy using methyl 3,5-dinitrobenzoate as an internal standard. 
<smiles>O=[N+]([O-])CC1c2ccccc2CCN1c1ccccc1</smiles>

3a: ${ }^{1} \mathrm{H}$ NMR (400 MHz, $\left.\mathrm{CDCl}_{3}\right) \delta$ 7.28-7.20 (m, 5H), 7.13 (d, $\left.J=7.3 \mathrm{~Hz}, 1 \mathrm{H}\right), 6.98(\mathrm{~d}, J=8.5 \mathrm{~Hz}$, 2H), $6.86(\mathrm{t}, J=7.3 \mathrm{~Hz}, 1 \mathrm{H}), 5.55(\mathrm{t}, J=7.8 \mathrm{~Hz}, 1 \mathrm{H}), 4.87(\mathrm{dd}, J=11.5,7.8 \mathrm{~Hz}, 1 \mathrm{H}), 4.57(\mathrm{dd}, \mathrm{J}=$ 12.0, $6.8 \mathrm{~Hz}, 1 \mathrm{H}), 3.69-3.60(\mathrm{~m}, 2 \mathrm{H}), 3.11-3.03(\mathrm{~m}, 1 \mathrm{H}), 2.79(\mathrm{dt}, J=16.3,5.0 \mathrm{~Hz}, 1 \mathrm{H})$.<smiles>CC(C1c2ccccc2CCN1c1ccccc1)[N+](=O)[O-]</smiles>

3b: ${ }^{1} \mathrm{H}$ NMR (400 MHz, $\left.\mathrm{CDCl}_{3}\right) \delta$ 7.29-7.09 (m, 6H), 7.02-6.97 (m, 2H), 6.83-6.79 (m, 1H), 5.26-5.22 (m, 1H), [5.10-5.01 (m), 4.94-4.84 (m), 1H], [3.89-3.80 (m), 3.62-3.53 (m), 2H], [3.11-3.01 (m), 2.96-2.83 (m), 1H)], [1.69 (d, J=6.9 Hz), $1.53(\mathrm{~d}, \mathrm{~J}=6.9 \mathrm{~Hz}), 3 \mathrm{H}]$.<smiles>CCC(C1c2ccccc2CCN1c1ccccc1)[N+](=O)[O-]</smiles>

3c: ${ }^{1} \mathrm{H}$ NMR $\left(400 \mathrm{MHz}, \mathrm{CDCl}_{3}\right) \delta$ 7.28-7.12 (m, 6H), 6.99-6.92 (m, 2H), 6.83-6.77 (m, 1H), [5.24 $(\mathrm{d}, J=9.1 \mathrm{~Hz}), 5.12(\mathrm{~d}, J=9.2 \mathrm{~Hz}), 1 \mathrm{H}],[4.89-4.84(\mathrm{~m}), 4.70-4.65(\mathrm{~m}), 1 \mathrm{H}],[3.88-3.81(\mathrm{~m})$, 3.69-3.49 (m), 2H], [3.10-3.03 (m), 2.93-2.83 (m), 2H], [2.16-2.05 (m), 1.89-1.78 (m), 2H], 0.95-0.92 (m, 3H).

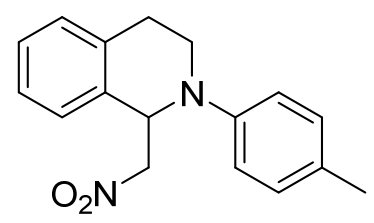

3d: ${ }^{1} \mathrm{H}$ NMR (400 MHz, $\left.\mathrm{CDCl}_{3}\right) \delta$ 7.27-7.10 (m, 4H), $7.06(\mathrm{~d}, J=8.5 \mathrm{~Hz}, 2 \mathrm{H}), 6.88(\mathrm{~d}, J=8.5 \mathrm{~Hz}$, 2H), 5.47 (t, $J=7.9 \mathrm{~Hz}, 1 \mathrm{H}), 4.82(\mathrm{dd}, J=12.0,8.1 \mathrm{~Hz}, 1 \mathrm{H}), 4.54(\mathrm{dd}, J=12.0,7.0 \mathrm{~Hz}, 1 \mathrm{H})$, 3.62-3.51 (m, 2H), 3.06-3.01 (m, 1H), $2.72(\mathrm{dt}, J=16.0,4.1 \mathrm{~Hz}, 1 \mathrm{H}), 2.25(\mathrm{~s}, 3 \mathrm{H})$. 


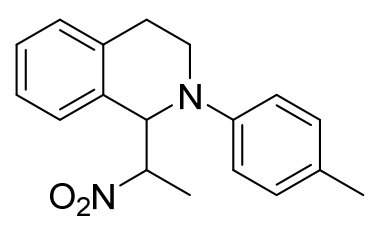

3e: ${ }^{1} \mathrm{H}$ NMR $\left(400 \mathrm{MHz}, \mathrm{CDCl}_{3}\right) \delta$ 7.25-6.99 (m, $\left.6 \mathrm{H}\right), 6.92-6.87$ (m, 2H), 5.20-5.12 (m, $\left.1 \mathrm{H}\right)$, 5.04-4.85 (m, 1H), [3.83-3.76 (m), 3.59-3.48 (m), 2H], [3.07-2.96 (m), 2.91-2.77 (m), 2H], [2.25 (s), $2.23(\mathrm{~s}), 3 \mathrm{H}],[1.67(\mathrm{~d}, J=6.9 \mathrm{~Hz}), 1.51(\mathrm{~d}, J=6.9), 3 \mathrm{H}]$.

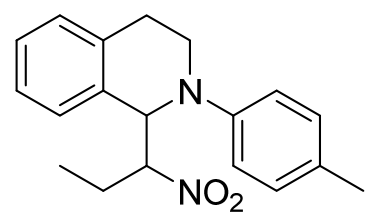

3f: ${ }^{1} \mathrm{H}$ NMR $\left(400 \mathrm{MHz}, \mathrm{CDCl}_{3}\right) \delta$ 7.25-6.95 (m, 3H), 6.89-6.80 (m, 2H), [5.15 (d, J=12.0 Hz), 5.04 $(\mathrm{d}, J=9.5 \mathrm{~Hz}), 1 \mathrm{H}],[4.87-4.80(\mathrm{~m}), 4.69-4.62(\mathrm{~m}), 1 \mathrm{H}],[3.65-3.79(\mathrm{~m}), 3.64-3.45(\mathrm{~m}), 2 \mathrm{H}]$, [3.05-2.98 (m), 2.88-2.75 (m), 2H], $2.30(\mathrm{~s}, 3 \mathrm{H}),[2.17-2.01(\mathrm{~m}), 1.88-1.76(\mathrm{~m}), 2 \mathrm{H}], 0.90-0.95(\mathrm{~m}$, $3 \mathrm{H})$.

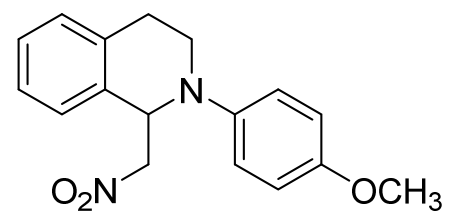

3g: ${ }^{1} \mathrm{H}$ NMR $\left(400 \mathrm{MHz}, \mathrm{CDCl}_{3}\right) \delta$ 7.28-7.13 (m, 4H), $6.91(\mathrm{~d}, J=9.0 \mathrm{~Hz}, 2 \mathrm{H}), 6.80(\mathrm{~d}, J=9.0 \mathrm{~Hz}$, 2H), 5.39 (dd, $J=8.6,5.8 \mathrm{~Hz}, 1 \mathrm{H}), 4.82(\mathrm{dd}, J=11.9,8.6 \mathrm{~Hz}, 1 \mathrm{H}), 4.56(\mathrm{dd}, J=11.9,5.8 \mathrm{~Hz}, 1 \mathrm{H})$, $3.75(\mathrm{~s}, 3 \mathrm{H}), 3.62-3.52(\mathrm{~m}, 2 \mathrm{H}), 3.06-2.98(\mathrm{~m}, 1 \mathrm{H}), 2.70(\mathrm{dt}, \mathrm{J}=16.5,4.1 \mathrm{~Hz}, 1 \mathrm{H})$.<smiles>COc1ccccc1N1CCc2ccccc2C1CN=O</smiles>

3h: ${ }^{1} \mathrm{H}$ NMR (400 MHz, $\left.\mathrm{CDCl}_{3}\right) \delta$ 7.24-7.12 (m, 4H), 7.05-7.01 (m, 1H), 6.90-6.81 (m, 3H), 5.52 (dd, $J=8.0,5.0 \mathrm{~Hz}, 1 \mathrm{H}), 4.81(\mathrm{dd}, J=12.0,8.6 \mathrm{~Hz}, 1 \mathrm{H}), 4.52(\mathrm{dd}, J=12.0,5.2,1 \mathrm{H}), 3.82(\mathrm{~s}, 3 \mathrm{H})$, 3.44-3.61 (m, $2 \mathrm{H}), 3.01-2.94(\mathrm{~m}, 1 \mathrm{H}), 2.79-2.74(\mathrm{~m}, 1 \mathrm{H})$. 


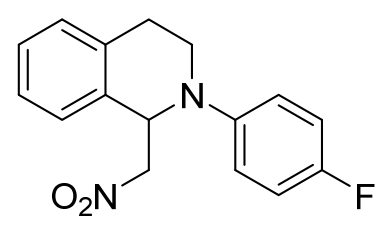

3i: ${ }^{1} \mathrm{H}$ NMR $\left(400 \mathrm{MHz}, \mathrm{CDCl}_{3}\right) \delta$ 7.27-7.11 (m, 4H), 6.91-6.87 (m, 4H), $5.43(\mathrm{dd}, J=8.5,5.9 \mathrm{~Hz}$, $1 \mathrm{H}), 4.84(\mathrm{dd}, J=12.1 \mathrm{~Hz}, 8.7 \mathrm{~Hz}, 1 \mathrm{H}), 4.57$ (dd, $J=12.0 \mathrm{~Hz}, 5.9 \mathrm{~Hz}, 1 \mathrm{H}), 3.67-3.52(\mathrm{~m}, 2 \mathrm{H})$, 3.03-2.96 (m, 1H), $2.71(\mathrm{dt}, J=16.3 \mathrm{~Hz}, 4.2 \mathrm{~Hz}, 1 \mathrm{H})$

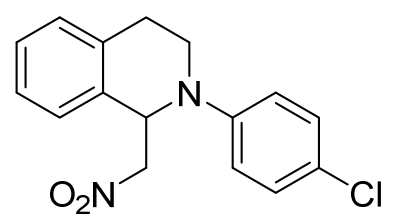

3j: ${ }^{1} \mathrm{H}$ NMR $\left(400 \mathrm{MHz}, \mathrm{CDCl}_{3}\right) \delta$ 7.28-7.11 (m, 6H), $6.88(\mathrm{~d}, J=9.0 \mathrm{~Hz}, 2 \mathrm{H}), 5.48(\mathrm{t}, J=7.5 \mathrm{~Hz}$, $1 \mathrm{H}), 4.83(\mathrm{dd}, J=11.9,8.2 \mathrm{~Hz}, 1 \mathrm{H}), 4.56$ (dd, $J=12.0,6.3 \mathrm{~Hz}, 1 \mathrm{H}), 3.68-3.51$ (m, 2H), 3.04 (ddd, $J$ $=15.4,8.5,6.2 \mathrm{~Hz}, 1 \mathrm{H}), 2.77(\mathrm{dt}, J=16.1,4.6 \mathrm{~Hz}, 1 \mathrm{H})$.

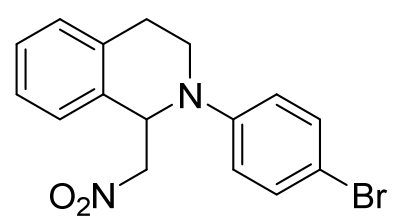

3k: ${ }^{1} \mathrm{H}$ NMR $\left(400 \mathrm{MHz} \mathrm{CDCl}_{3}\right) \delta 7.34(\mathrm{~d}, J=8.8 \mathrm{~Hz}, 2 \mathrm{H}), 7.30-7.11(\mathrm{~m}, 4 \mathrm{H}), 6.84(\mathrm{~d}, J=8.8 \mathrm{~Hz}$, 2H), $5.48(\mathrm{t}, J=8.0 \mathrm{~Hz}, 1 \mathrm{H}), 4.85(\mathrm{dd}, J=12.0,8.0 \mathrm{~Hz}, 1 \mathrm{H}), 4.57$ (dd, $J=12.0,6.8 \mathrm{~Hz}, 1 \mathrm{H})$, 3.68-3.54 (m, 2H), 3.14-3.01 (m, 1H), $2.79(\mathrm{dt}, J=16.1,4.8,1 \mathrm{H})$.

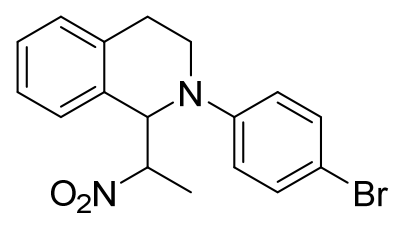

3l: ${ }^{1} \mathrm{H}$ NMR $\left(400 \mathrm{MHz}, \mathrm{CDCl}_{3}\right) \delta$ 7.36-7.01 (m, $\left.6 \mathrm{H}\right), 6.85-6.83(\mathrm{~m}, 2 \mathrm{H})$, 5.20-5.13 (m, $\left.1 \mathrm{H}\right)$, [5.03-4.99 (m), 4.90-4.84 (m), 1H], [3.83-3.78 (m), 3.60-3.46 (m), 2H], [3.07-3.01 (m), 2.95-2.85 (m), 2H], [1.67 (d, $J=6.8 \mathrm{~Hz}), 1.55(\mathrm{~d}, J=6.8), 3 \mathrm{H}]$. 


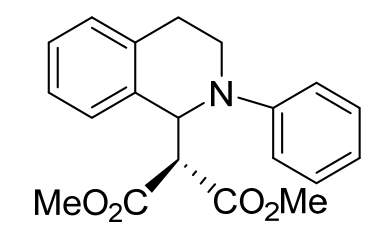

4a: ${ }^{1} \mathrm{H}$ NMR (400 MHz, $\left.\mathrm{CDCl}_{3}\right) \delta$ 7.28-7.08 (m, 6H), $6.98(\mathrm{~d}, J=8.0 \mathrm{~Hz}, 2 \mathrm{H}), 6.76(\mathrm{t}, J=7.2 \mathrm{~Hz}$, 1H), $5.71(\mathrm{~d}, 1 \mathrm{H}, J=9.3 \mathrm{~Hz}), 3.95$ (d, $J=9.4 \mathrm{~Hz}, 1 \mathrm{H}), 3.77-3.58(\mathrm{~m}, 5 \mathrm{H}), 3.55(\mathrm{~s}, 3 \mathrm{H}), 3.09$ (ddd, $J=15.6,9.0,6.3 \mathrm{~Hz}, 1 \mathrm{H}), 2.86(\mathrm{dt}, 1 \mathrm{H}, J=16.4,5.0 \mathrm{~Hz})$.

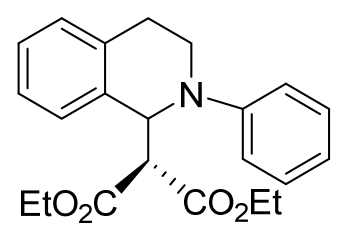

4b: ${ }^{1} \mathrm{H}$ NMR $\left(400 \mathrm{MHz}, \mathrm{CDCl}_{3}\right) \delta$ 7.26-7.08 (m, $\left.6 \mathrm{H}\right), 6.98(\mathrm{~d}, J=8.0 \mathrm{~Hz}, 2 \mathrm{H}), 6.76(\mathrm{t}, J=7.3 \mathrm{~Hz}$, 1H), $5.73(\mathrm{~d}, J=9.2 \mathrm{~Hz}, 1 \mathrm{H}), 4.23-3.95(\mathrm{~m}, 4 \mathrm{H}), 3.92(\mathrm{~d}, J=9.2 \mathrm{~Hz}, 1 \mathrm{H}), 3.75-3.60(\mathrm{~m}, 2 \mathrm{H})$, 3.10-3.02 (m, $1 \mathrm{H}), 2.87(\mathrm{dt}, J=16.4,5.2 \mathrm{~Hz}, 1 \mathrm{H}), 1.17(\mathrm{t}, J=7.1 \mathrm{~Hz}, 3 \mathrm{H}), 1.09$ (t, $J=7.1 \mathrm{~Hz}, 3 \mathrm{H})$.

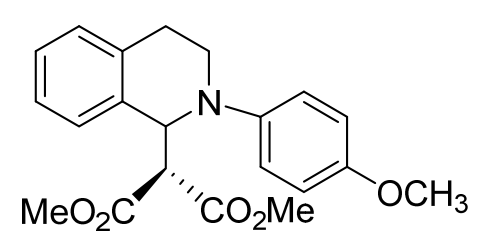

4c: ${ }^{1} \mathrm{H}$ NMR (400 MHz, $\left.\mathrm{CDCl}_{3}\right) \delta$ 7.20-7.15 (m, 2H), 7.10-7.08 (m, 2H), $6.95(\mathrm{~d}, J=9.1 \mathrm{~Hz}, 2 \mathrm{H})$, $6.78(\mathrm{~d}, J=9.1 \mathrm{~Hz}, 2 \mathrm{H}), 5.48(\mathrm{~d}, J=9.4 \mathrm{~Hz}, 1 \mathrm{H}), 3.97(\mathrm{~d}, J=9.4 \mathrm{~Hz}, 1 \mathrm{H}), 3.72(\mathrm{~s}, 3 \mathrm{H}), 3.69-3.63(\mathrm{~m}$, 4H), $3.61(\mathrm{~s}, 3 \mathrm{H}), 3.58-3.53(\mathrm{~m}, 1 \mathrm{H}), 3.01(\mathrm{ddd}, J=16.6,10.2,6.3 \mathrm{~Hz}, 1 \mathrm{H}), 2.74(\mathrm{dt}, J=16.7,4.4 \mathrm{~Hz}$, $1 \mathrm{H})$.<smiles>CC(=O)CC1c2ccccc2CCN1c1ccccc1</smiles>

5a: ${ }^{1} \mathrm{H}$ NMR $\left(400 \mathrm{MHz}, \mathrm{CDCl}_{3}\right) \delta$ 7.26-7.12 (m, 6H), $6.93(\mathrm{~d}, J=8.3 \mathrm{~Hz}, 2 \mathrm{H}), 6.77(\mathrm{t}, J=7.8 \mathrm{~Hz}$, $1 \mathrm{H}), 5.40(\mathrm{t}, J=7.2 \mathrm{~Hz}, 1 \mathrm{H}), 3.64-3.46(\mathrm{~m}, 2 \mathrm{H}), 3.08-3.02(\mathrm{~m}, 2 \mathrm{H}), 2.82(\mathrm{dt}, J=16.6,4.5 \mathrm{~Hz}, 2 \mathrm{H})$, $2.07(\mathrm{~s}, 3 \mathrm{H})$. 


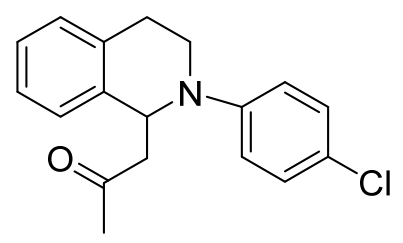

5b: ${ }^{1} \mathrm{H}$ NMR (400 MHz, $\left.\mathrm{CDCl}_{3}\right) \delta 7.20-7.11(\mathrm{~m}, 6 \mathrm{H}), 6.84(\mathrm{~d}, J=9.1 \mathrm{~Hz}, 2 \mathrm{H}), 5.33(\mathrm{t}, J=6.8 \mathrm{~Hz}$, $1 \mathrm{H}), 3.60-3.47$ (m, 2H), 3.06-3.00 (m, 2H), 2.86-2.78 (m, 2H), 2.09 (s, 3H).

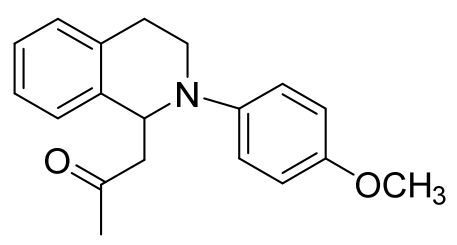

5c: ${ }^{1} \mathrm{H}$ NMR $\left(400 \mathrm{MHz}, \mathrm{CDCl}_{3}\right) \delta$ 7.22-7.07 (m, 4H), $6.91(\mathrm{~d}, J=9.1,2 \mathrm{H}), 6.81(\mathrm{~d}, \mathrm{~J}=9.3 \mathrm{~Hz}, 2 \mathrm{H})$, $5.25(\mathrm{t}, J=6.4 \mathrm{~Hz}, 1 \mathrm{H}), 3.75(\mathrm{~s}, 3 \mathrm{H}), 3.62-3.40(\mathrm{~m}, 2 \mathrm{H}), 3.02-2.96(\mathrm{~m}, 2 \mathrm{H}), 2.78-2.70(\mathrm{~m}, 2 \mathrm{H}), 2.05$ (s, 3H). 